\title{
AC 2010-1628: COMMUNITY COLLEGES CAN HELP UNIVERSITIES DURING ABET ACCREDITATION EFFORTS
}

\section{Dan Dimitriu, San Antonio College}

DAN G. DIMITRIU has been practicing engineering since 1970 and taught engineering courses concurrently for over 20 years. He has been involved with several engineering societies and was elected vice-chair of the Two-Year College Division of ASEE in 2005. He has been the coordinator of the Engineering Program at San Antonio College since 2001. His research interests are: alternative fuels, fuel cells, plastics, and engineering education.

\section{Jerry O'Connor, San Antonio College}

JERRY O'CONNOR has been teaching physics (and a few engineering courses) at San Antonio College since 1987. He was the Campus Coordinator for the Texas Alliance for Minority Participation program from 1993 to 2002, and is currently the Department Chairperson for Physics, Engineering, \& Architecture. He has been involved in numerous initiatives to integrate the findings of physics and engineering education research with education practice. 


\title{
Community Colleges Can Help Universities During
}

\author{
ABET Accreditation Efforts
}

\begin{abstract}
Every Engineering program in the U.S. accredited by ABET undergoes a review process every six years. These reviews require extensive preparation, including data collection and analysis to demonstrate specified outcomes. These periodic reviews are meant to stimulate a thorough assessment and evaluation of programs, and often result in curriculum changes such as new, modified, or discontinued courses.

During this review process it seems like Two Year Colleges that have aligned their programs with the University Program are usually left out of the loop, even though they might prepare a substantial number of students for transfer. Previous reports have estimated that $20 \%$ of the engineers in United States began their academic studies at a community college and $40 \%$ of the recipients of Bachelor's and Master's degrees in Engineering attended a community college. This communication gap thus possesses the potential to significantly and adversely affect the progress of engineering students through the proverbial pipeline.

At this time there is no ABET accreditation process for two-year Engineering Science programs, as there is for two-year Engineering Technology programs. Apart from a few state or local initiatives, no other institution, organization, or agency is known to provide either a general framework or specific guidelines for helping Two Year Colleges establish a corresponding review process that would connect with the University Programs and assist with the accreditation process and development of effective transfer programs.

The paper attempts to provide some guidelines to help Community Colleges develop a productive ongoing dialog to cultivate active partnerships with four-year universities. These partnerships should be based on a comprehensive and unified approach to the accreditation process. Successful efforts will be rewarded with easier accreditation reviews, stronger ties between the two institutions, and better programs that will attract and retain more students in the engineering disciplines.
\end{abstract}

\section{Introduction}

Community colleges, which are serving increasing numbers of minorities, women, and nontraditional students, offer an unrealized opportunity to be beneficial partners in science, math, and engineering education. Most community colleges deliver quality and affordable programs that are easily accessible, while providing initial and life-long educational opportunities ${ }^{1,2}$. It is generally estimated that about $20 \%$ of the engineers in United States began their academic studies at a community college and $40 \%$ of the recent recipients of bachelor's and master's degrees in engineering attended a community college ${ }^{3}$. These figures represent only a small fraction of the community college population, and studies also indicate that some underrepresented populations are more likely to begin their college studies at a community college. This implies that there is a significant reservoir of students at the community college 
level that might be attracted to the Engineering Profession. This source of students could help meet anticipated shortages and diversity goals if two and four-year institutions have well coordinated programs. 4

Despite these realities, there is currently no accreditation process in place for engineering science programs in two-year colleges as there is for two-year engineering technology programs. No institution, organization, or agency is known to provide systemic guidelines for the assessment and evaluation of transfer programs for the traditional engineering disciplines. The only support from ABET in this domain is in Criterion 1 of the current ABET accreditation guidelines Students - which contains a requirement that a four-year program seeking accreditation or reaccreditation "must have and enforce policies for the acceptance of transfer students and for the validation of courses taken for credit elsewhere."

This situation invites two-year colleges (TYC's) to take proactive actions to support their fouryear partners in their quest to meet ABET accreditation criteria. A listing of these criteria along with some possible ways TYC's can adjust their programs to meet the criteria may be helpful in helping four-year institutions obtain accreditation while also strengthening their partnerships with local community college programs.

\section{ABET Accreditation Criteria}

\section{Criterion 1. Students}

Community college program are also obligated to evaluate student performance, provide advising for students regarding curricular and career matters, and monitor student's progress to foster their success in achieving program outcomes. The TYC engineering programs must be familiar with, and need to be informed of changes, in their partnering four-year engineering programs in order to harmonize their curricula. In addition to providing equivalent coursework, TYC's can work with their university partners to obtain data to evaluate the post-transfer success of TYC students. Since many students arrive at community colleges underprepared, the TYC programs should have and enforce policies and procedures to ensure that students who complete the TYC program meet all corresponding requirements of the four-year institution's program.

\section{Criterion 2. Program Educational Objectives}

Since each program for which a four-year institution seeks accreditation or reaccreditation must have in place specific educational objectives, it behooves community college programs to adopt objectives for their programs that are consistent. Although TYC programs typically have a greater diversity of students with various backgrounds, levels of preparation, knowledge, and skills, they may have to provide a broader range of objectives, but still must maintain a level of program standards that match those of their partnering university programs. ${ }^{6}$ It is advised that two-year programs initiate an independent process that will allow them to document and demonstrate that their students are meeting the objectives corresponding to those of the four-year institutions where the students transfer. The programs at both institutions would stand to gain from a discussion of their assessment and evaluation processes and factors that influence the degree to which the objectives are attained. 


\section{Criterion 3. Program Outcomes}

Since community colleges address only the first two years of higher education, not all of the specified ABET bachelor program educational objectives will pertain to their programs. Nonetheless, a substantial portion of the a-k outcomes can be supported at the TYC level:

- the ability to apply knowledge of mathematics, science, and engineering (a)

- the ability to design and conduct experiments, as well as to analyze and interpret basic data (b)

- the ability to function in teams (d)

- understanding of professional and ethical responsibility (f)

- the ability to communicate effectively (g)

- a recognition of the need for, and an ability to engage in life-long learning (i)

- a knowledge of contemporary issues (j)

- the ability to use some of the basic techniques, skills, and modern engineering tools necessary for engineering practice $(\mathrm{k})$.

If these outcomes are clearly articulated and effectively assessed by the TYC program, this will help the program articulate smoothly with the engineering program(s) at the four-year institutions. Community college programs are advised to work with their four-year partner(s) to develop an assessment and evaluation process that defines and demonstrates the degree to which the appropriate outcomes are attained at the two-year level.

\section{Criterion 4. Continuous Improvement}

Community colleges are usually obligated by their own accrediting body to show evidence that program results are being monitored and that the information acquired is used for program improvement. It could be very advantageous for the TYC to become familiar with how their four-year partner(s) are documenting this process. This would not only provide a relevant frame of reference for the TYC to document its own process, it would reinforce important program elements and strengthen the four-year program's bid for accreditation.

\section{Criterion 5. Curriculum}

Although community colleges are limited to offering only lower division curriculum, this area comprises a substantial portion of the professional component of the engineering curriculum prescribed by ABET. This includes college level mathematics and basic sciences, the general education component that complements the technical content of the engineering curriculum, and an introduction to creative application. A more secure foundation for the bridge between mathematics and basic sciences and engineering practice can be established when two and fouryear programs work together to build it. Due to the more fundamental focus on basic science and mathematics at community colleges, they present several advantages to students starting their engineering education there. ${ }^{7}$

\section{Criterion 6. Faculty}

The primary focus of TYC engineering programs is at the foundational level where mathematics 
and science competencies can be maintained as strictly as those at a four-year institution. In order to establish the bridging connections with engineering practice, community colleges can recruit a variety of practicing or retired engineers that have a wealth of industry related experience and willingness to share it with students. The flexible hours and emphasis on teaching instead of research provides an environment where students can learn how the engineering design process has been used to solve real-life problems.

\section{Criterion 7. Facilities}

Although significant variations may exist in the classrooms, laboratories, equipment, and software provided by both two and four-year institutions, the focus must be on creating a learning environment to safely achieve the specified program objectives. Universities do not have a monopoly on facilities that foster student-faculty interaction and encourage student and faculty participation in professional development activities.

\section{Criterion 8. Support}

Since two-year engineering science programs are not currently accredited, the quality and continuity of institutional support, financial resources, and adaptive leadership may be subject to greater variation than most four-year programs. Strong partnerships and effective articulation agreements with four-year institutions can help reduce the magnitude of this variation. All institutions are subject to financial and visionary vicissitudes, and during times of adversity essential resources tend to flow toward flourishing programs. Documentation of successful program outcomes and student transfers can be a bulwark against cutbacks at TYC's.

\section{Criterion 9. Program Criteria}

Community college programs need to be aware of any specific Program Criteria their partnering four-year institutions may have established. Including applicable criteria in the TYC program review process will help ensure the success of transfer students and maintain the viability of articulation agreements. The documentation of these criteria over the entire span of undergraduate engineering education helps two and four-year programs alike in their quest for affirmation.

\section{Conclusions}

In order to initiate and preserve secure and productive relationships with engineering programs at four-year institutions in their service area, engineering faculty and administrators at community colleges are advised to increase their awareness of the ABET Accreditation Criteria and become more familiar with how the four-year institutions satisfy those criteria. By integrating appropriate elements of these criteria into their own review and accreditation process, TYC programs can strengthen their articulation agreements and enhance the success of their transfer students. Ongoing communication between two and four year programs will generate favorable conditions to address common concerns and share best practices that will support both institutions' efforts in maintaining their respective accreditations, which will in turn help prepare more students for successful engineering careers. 


\section{References:}

1. http://www.nsf.gov/about/congress/107/hs_030702undergraded.jsp

2. http://www.hewlett.org/Programs/Education/Opportunity/News/eswiNewsRelease.htm

3. Enhancing the Community College Pathway to Engineering Careers, The National Academies Press, 2005, Washington D.C.

4. Forging Stronger Ties Between Community Colleges and Four Year Universities, by Dan Dimitriu and Jerry O'Connor, Proceedings of the 2004 ASEE Annual Conference \& Exposition

5. Engineering Criteria 2000, - Accreditation Board for Engineering and Technology, URL: < www.abet.org >

6. The Need for a Quality Control System for Community College Engineering Education, by Dan Dimitriu and Jerry O'Connor, Proceedings of the 2007 ASEE Annual Conference \& Exposition

7. The Advantages of Starting an Engineering Education at a Community College, by Dan Dimitriu and Jerry O'Connor, Proceedings of the 2006 ASEE Annual Conference \& Exposition 